\title{
Evolving Strategies for the Structuring of Working Capital Loans during Covid Times: An Analysis of Select Indian Private Sector Banks
}

\author{
BEILA SEHDEV ${ }^{1}$, DR. T.V. RAMAN ${ }^{2}$, DR. MAHENDRA RANAWAT ${ }^{3}$ \\ ${ }^{1}$ Research Scholar, Amity Business School, AMITY UNIVERSITY NOIDA, Uttar Pradesh, INDIA \\ E-mail: beilasehdev@gmail.com \\ ${ }^{2}$ Professor, Amity Business School, AMITY UNIVERSITY NOIDA, Uttar Pradesh, INDIA \\ ${ }^{3}$ Professor, BN UNIVERSITY, Udaipur, Rajasthan, INDIA
}

\begin{abstract}
Predicting human behavior is a difficult task, yet bankers perform this regularly while sanctioning working capital loans, so that money advanced is recoverable. For this, they try to assess credit worthiness of clients based on past performance through financials and banking habits amongst other parameters. Clients also look at fees and instalment burden, duration of loan, etc. However, with the adverse impact of Covid pandemic on earning capacities, banks need to relook at the way they structure loans. This perspective, which has evolved with the pandemic, needs to be explored. With this in mind, an undisguised structured questionnaire was administered on 322 respondents who had availed working capital loans from top five private sector banks of India. The selection was done using stratified random and judgemental sampling techniques. Thereafter, correlation and multiple regression analysis were used on SPSS platform to understand relationship between various credit parameters assessed by both the parties to a loan and then structure a best-fit loan. The study suggested that customer-focused, risk-adjusted analysis for working capital loans should be undertaken to reduce nonperforming assets and improve asset portfolio quality of banks.
\end{abstract}

Keywords: Credit Parameters; Loan Structuring; Private Sector Banks; Working Capital Loans.

JEL Classification: E50, E51, H80

Received: June 15, 2021

Accepted: October 13, 2021 


\title{
Estrategias Evolutivas para la Estructuración de los Préstamos de Capital Circulante en Tiempos de Crisis: Un Análisis de algunos Bancos del Sector Privado de la India
}

\author{
BEILA SEHDEV ${ }^{1}$, DR. T.V. RAMAN ${ }^{2}$, DR. MAHENDRA RANAWAT ${ }^{3}$ \\ ${ }^{1}$ Research Scholar, Amity Business School, AMITY UNIVERSITY NOIDA, Uttar Pradesh, INDIA \\ E-mail: beilasehdev@gmail.com \\ ${ }^{2}$ Professor, Amity Business School, AMITY UNIVERSITY NOIDA, Uttar Pradesh, INDIA \\ ${ }^{3}$ Professor, BN UNIVERSITY, Udaipur, Rajasthan, INDIA
}

\begin{abstract}
RESUMEN
Predecir el comportamiento humano es una tarea difícil, pero los banqueros la llevan a cabo con regularidad cuando conceden préstamos de capital circulante, para que el dinero adelantado sea recuperable. Para ello, intentan evaluar la solvencia de los clientes basándose en sus resultados anteriores a través de sus finanzas y hábitos bancarios, entre otros parámetros. Los clientes también se fijan en las comisiones y la carga de las cuotas, la duración del préstamo, etc. Sin embargo, con el impacto adverso de la pandemia de Covid en la capacidad de ganancia, los bancos deben replantearse la forma en que estructuran los préstamos. Esta perspectiva, que ha evolucionado con la pandemia, debe ser explorada. Teniendo esto en cuenta, se administró un cuestionario estructurado no disimulado a 322 encuestados que habían obtenido préstamos de capital circulante de los cinco principales bancos del sector privado de la India. La selección se llevó a cabo mediante técnicas de muestreo aleatorio estratificado y de juicio. A continuación, se utilizó el análisis de correlación y regresión múltiple en la plataforma SPSS para comprender la relación entre los diversos parámetros crediticios evaluados por ambas partes de un préstamo y, a continuación, estructurar el préstamo más adecuado. El estudio sugiere que debería realizarse un análisis centrado en el cliente y ajustado al riesgo para los préstamos de capital circulante a fin de reducir los activos improductivos y mejorar la calidad de la cartera de activos de los bancos.
\end{abstract}

Palabras clave: Parámetros de crédito; Estructuración de préstamos; Bancos del sector privado; Préstamos para capital circulante.

Clasificación JEL: E50, E51, H80

Recibido: 15 de Junio de 2021

Aceptado: 13 de Octubre de 2021 


\section{Introduction}

The banking industry plays a very vital role in money circulation and capital formation. Banks mobilize deposits from general public and advance this amount for personal and business needs of individuals and companies. These loans are given for both consumption and productive purposes. Loans which are given for day to day functioning of businesses are called working capital loans and are advanced in the form of overdraft facilities, cash credit limits, term loans, business loans, bills purchased or discounted, packing credit, letter of credit, bank guarantee and the likes (https://www.axisbank.com). Banks have product specific policies for all types of loans and are required to inform the customers desirous of availing these facilities about them.

These policies consider various factors or parameters to assess loan eligibility of a customer. These credit parameters considered by a bank include type of borrower profile which could be salaried or self-employed, age of the individual borrower, duration of work experience or vintage of business and nature of industry in which the borrower is employed or operates (https://www.hdfcbank.com). The industry in which a client works is classified as positive or negative depending on its economic viability. Generally, if a borrower belongs to a 'positive' industry and has more work experience or vintage, it depicts stability in employment.

The loan eligibility is evaluated based on income or financial performance of the customer (https://www.icicibank.com). In addition, banking habits and credit history i.e., inward and outward cheque returns, penalty on default in repayment of interest or installment of loans, regularity in repayment of earlier loans availed, etc. are also looked into not only in bank statements but also in loan repayment records. Timely repayment or healthy track record of loans previously availed shows financial discipline coupled with profitability. This indicates safety of money lent.

Further, security provided by the borrower is also scrutinized. Security could be primary or secondary in nature. Primary security for working capital loans are the current assets which are the debtors and stock needed for business; the secondary security could be residential, commercial, industrial property or near liquid securities like fixed deposits, life insurance policy, etc. as deemed fit by the lender. Documentation that a borrower executes depends on security provided against the loan, type of loan availed as well as profile of the borrower (https://www.yesbank.in).

Based on the above analysis, rate of interest and fees to be charged, duration of loan, installment payable, security required and documents to be executed are communicated to the borrower (https://www.kotak.com). Accordingly, a customer selects a bank which offers loans on terms most suitable to him or her and the banks also select customers which fit into their policy parameters and approve or reject the loan.

This research is an attempt to study the lending norms of select private sector banks for working capital borrowers in small and medium enterprises (SMEs). The correlation between the parameters looked at by borrowers and bankers as discussed above has been analyzed to understand that while currently loans are structured on the past performance of customers in the context of financial capability, banking habits, and repayment records, the need of the hour during covid scenario is to look at them on a case to case basis by adjusting them for risk perceived based on customer profile.

With this in mind, multiple regression has been used to analyze those dependent variables looked at by borrowers, with independent variables being credit parameters evaluated by banks that show a significant relationship. Using these, banks might then be able to offer profile-based loans, thereby minimizing the incidence of default, reducing non-performing assets, and improving their asset portfolio quality in the long run.

\section{Literature Review}

Granting advances is a major activity of banks but it is also a cause for concern as it includes the risks of delinquency and non-repayment. According to guidelines post Basel II Accord, banks should develop their own risk assessment systems as far as lending is concerned. However, the accuracy of 
these models in predicting customer default is debatable as human inclinations and judgements are unpredictable and volatile. Despite these constraints, many researches have been conducted on the banking industry. According to a report published by Dun and Bradstreet (2017), top five Indian private sector banks on the basis of Total Income, Advances and Deposits were HDFC Bank, ICICI Bank, Axis Bank, Kotak Mahindra Bank and Yes Bank and for this study, the focus is on these five banks.

As per some studies undertaken on the issue of asset quality, non- performing assets (NPAs) and loan assessment it was observed that one way of managing credit risk and thereby NPAs is through the process of credit appraisal. In line with this, Catherine (2020) observed that credit appraisal needs to be strong for effective credit risk management. Infact, the performance of the bank depends on client appraisal, credit risk control, and risk diversification. The study also recommended that banks should continuously assess their risk management practices in view of changing economic and business environment and the products should be tailored for customers' ease in understanding.

Some researchers like Ray (2020) felt that in the five decades post nationalization of banks, they have grown substantially in size and asset base but this growth has generated huge amount of nonperforming assets. This has adversely impacted their profitability thereby exposing managerial inefficiencies in the system. Faulty credit appraisal by untrained staff is one of the biggest contributor to managerial inefficiency leading to rising delinquencies. Other researchers like Palli (2019) held the view that banks should have access to past track records of borrowers so as to form an opinion and conduct financial background checks. He felt that in order to ensure a robust system, credit team of banks should undergo periodic training to update their skills on industry benchmarks and credit evaluation processes.

According to Dhanya and Vanaja (2018) credit appraisal is based on fundamental soundness which involves checking the technical and financial feasibility of the loan, funding pattern and the collateral or primary security cover available for the recovery of money lent. As per them, the factors considered by banks at the time of loan assessment are financial and business performance, industry outlook, quality of the management and conduct of the account. Stringent credit appraisal and sound lending process will lead to a healthy portfolio and profitability of banks (Kumar et al., 2018). Similarly, loans sanctioned with no pre-inquiry about the customers' business and financial performance and poor credit management policies on part of the bank would lead to non-performing assets (Banerjee, Verma and Jaiswal, 2018).

Infact, the unprecedented growth in NPAs in the Indian Banking industry was a reflection of incorrect credit appraisal and inefficient recovery mechanism. Faulty lending policies and priority sector lending also added to this increasing rate of NPAs (Chaitra and Vasu, 2018). A totally different thought process was seen in the research conducted by Patnaik, Satpathy and Samal, (2017) as per which the customers are bound to banks on account of service quality and promptness as well as fair and affordable pricing. To achieve this, banks should leverage technology for delivering products and services to customers in a secure, prompt and cost effective manner. Banks should therefore listen to customers and build analytics based on their interaction rather than financials of customers. Thus, use of credit scoring models should be used for credit decisioning to rule out subjectivity.

Further, Mishra and Pawaskar (2017) were also of the view that banks are exposed to different types of risks like credit risk, liquidity risk, operational risk, interest risk, management risk and market risk. However one very important risk as per them was loan recovery as financial strength of a bank depends on the recovery of its loans or level of its NPAs. So banks should be diligent while selecting customers and sanctioning loans as well as have good credit appraisal system so as to prevent occurrence of NPAs. Credit-worthiness should be considered before sanctioning of loan (Mittal and Suneja, 2017). They were of the view that poor-credit appraisal, wrong borrower selection, absence of trained staff, staff with rigid attitude, improper follow-up mechanism and management of lending facilities are the bank related factors which lead to bad loans.

As per Sengupta and Vardhan (2017), NPAs can be traced to excessive advances. Then to support the financial sector, RBI allowed banks to suspend norms of income recognition and permitted 
restructuring of loans that could become non-performing. This made it easier for debt ridden companies to borrow more which led to a fresh wave of NPAs. This vicious cycle could have been prevented by initiating government policies that promoted growth. Banks should formulate proper credit appraisal techniques, collect complete information about the business, its financial performance, management, industry it operates in and conduct proper credit monitoring so as to be aware of loan requirements of borrowers as well as detect warning signals for taking speedy remedial action and preventing default (Sahni and Seth, 2017).

According to Shah and Sharma (2016), by following proper appraisal policy, NPAs can be minimized in the banking industry. So, banks should take precautions to avoid NPAs. Singh (2016) pointed that banks should follow up with customers at regular intervals through personal visits to avoid diversion of funds. Visits should also be made to closely monitor operations of borrowers units periodically. Zahoor and Jegadeeshwaran (2013) also analyzed that weak credit appraisal processes, slack credit monitoring and lack of appropriate follow-up lead to the creation of NPAs. In addition, external factors like industrial problems, market recession, natural calamities and other uncertainties are also responsible for NPA.

Studies like those undertaken by Singh (2013) stated that banks have an inefficient system of managing credit risk as they have neither fixed any pre-sanction loan appraisal accountability nor do they have realistic post-disbursement monitoring system. So, to avoid NPAs, banks should keep reviewing loans and identify stressed accounts on a recurring basis. Gupta (2012) observed that bank should evaluate the financial capability of the borrower before providing any credit facility. Infact, she was of the view that every bank should have its own credit rating process which would analyze the financial capacity of the borrower as also check the financial condition of the client on a regular basis. Further, the staff of the bank involved in sanctioning advances should be proficient and motivated to take necessary steps for preventing advances becoming NPAs (Chaudhary and Sharma, 2011).

\section{Objectives and Hypothesis}

Based on literature review and primary data collected, the main objectives of this research are:

1. To study the credit parameters of select private sector banks while sanctioning working capital loans to Small and Medium Enterprises.

2. To analyze the relationship between these parameters from a banker's and borrowers' perspective.

3. To suggest risk-adjusted structuring of loans to minimize the incidence of default and improve asset portfolio quality.

Based on the second objective, the hypothesis for the study $\mathrm{H}_{\mathrm{o}}$ is "There is no significant relationship between credit parameters looked at by bankers and borrowers."

\section{Research Methodology}

\subsection{Loan Products for the study}

Fund-based facility of overdraft and cash credit and non-fund-based facility of letter of credit and bank guarantee under working capital loans; term loans for business purpose, business loan, and commodity finance under agricultural advances have been considered. This nomenclature is as per the apex bank, Reserve Bank of India and followed by all the banks in India.

\subsection{Banks under study}

Top five private sector banks as per the study of Dun and Bradstreet (2017) on the basis of Total Income, Advances, and Deposits have been considered. 
Table 1: Banks selected for comparison of Lending Parameters

\begin{tabular}{|c|c|c|c|c|}
\hline Rank & Bank & $\begin{array}{c}\text { Total Income } \\
\text { (₹ Mn) }\end{array}$ & $\begin{array}{c}\text { Advances } \\
\text { (₹ Mn) }\end{array}$ & $\begin{array}{c}\text { Deposits } \\
\text { (₹ Mn) }\end{array}$ \\
\hline 1 & HDFC Bank Ltd & 816024.6 & 5545682.0 & 6436396.6 \\
\hline 2 & ICICl Bank Ltd & 736607.6 & 4642320.8 & 4900390.6 \\
\hline 3 & Axis Bank Ltd & 562334.7 & 3730693.5 & 4143787.9 \\
\hline 4 & Kotak Mahindra Bank Ltd & 211760.9 & 1360821.3 & 1574258.6 \\
\hline 5 & Yes Bank Ltd & 205814.0 & 1322626.8 & 1428738.6 \\
\hline
\end{tabular}

Source: Dun and Bradstreet (2017)

\subsection{Data Source}

The study has relied upon both primary and secondary sources of data collection. For the primary data, an undisguised structured questionnaire was administered to 322 respondents selected by using stratified random as well as judgemental sampling techniques.

On the basis of Dun and Bradstreet report, questionnaires were administered to borrowers who had availed fund based and non-fund based working capital facilities, term/business loans and commodity finance from the top five private sector banks. The questionnaires were received from 40 fund based and 10 non-fund based borrower each, 10 term loan users from all banks except Yes Bank Ltd and 8 commodity Finance users for all banks except Kotak Mahindra Bank Ltd. These banks were excluded due to minimal penetration in these sectors by the said banks. Further, the numbers for various products was determined on the basis of the judgement of respective bank officials.

Secondary data has been analyzed to study the norms and related processes of working capital loans used by banks under study, as well as publications of various researchers in similar fields.

\subsection{Research Tools}

Karl Pearson's Correlation Analysis has been applied to study the relationship between lending parameters from borrowers' and bankers' perspectives.

Thereafter, multiple regression has been used to analyze those dependent variables looked at by borrowers, with independent variables being credit parameters evaluated by banks that show a significant relationship. Similar analysis was used by Sharma and Kumar (2011) while examining the effect of working capital on profitability of Indian firms.

Dependent Variables are fees charged, loan installment payable, and duration of the loan; Independent Variables are vintage, nature of the industry, financial performance, banking habits, and repayment track record.

\section{Analysis \& Inference}

As inferred from the literature review and based on our study of banks under consideration, the following lending parameters have been considered that are looked at by prospective borrowers.

i. Fees Charged: This depends on the loan product, loan amount, or facility availed and varies across banks.

ii. Rate of Interest: It depends on the loan product availed, duration of the loan, and fixed or floating rate scheme opted for by the client. It also varies across banks but is benchmarked to macroeconomic parameters.

iii. Repayment installments: For overdrafts and cash credit facilities, interest on outstanding loan amounts is payable on a monthly basis. However, for a term loan, repayment is made through fixed equated monthly installments (EMIs).

iv. Duration of the loan: It depends on the scheme opted for. The duration for overdraft and cash credit is 12 months, and the facility is renewable at the expiry of this term. The account is renewed on the basis of track record and submission of financial documents required by the 
bank. Letter of Credit and Bank Guarantee are non-fund-based facilities given for a span of 12 months. Term loans like loans for the purchase of plant and machinery, equipment, or business loans are sanctioned for a span of more than one year, depending on the purpose of the loan.

v. Security: In an overdraft facility, residential or commercial, or industrial property can be taken as security, while in the case of cash credit facility, charge on current assets (stocks and debtors) supported with residential or commercial or industrial property is considered. For term loans, the asset against which the loan has been given is the primary security. Where this security is not sufficient, additional security like fixed deposits, insurance, etc., can be taken for extra comfort by the lender.

vi. Documentation required: These vary with the nature of loan required, source of income of the borrower, nature of the property being provided, etc. In certain circumstances, banks can also ask for additional documents in order to substantiate the loan being asked for.

vii. Customer Service: The service should provide ease to the client in transacting. All the requirements should be communicated and queries answered in one go. Thus the experience should not be time-consuming but rather cost-effective.

From the bankers' perspective, the following parameters are looked at while sanctioning loans:

i. Profile of the customer.

ii. Vintage or total length of being in business or service in year terms.

iii. Nature of the industry in which borrower works.

iv. Financial performance of the borrower measured as cash-flow or profit in Rupee terms.

v. Banking history to check repayment behavior and credit history.

vi. Track Records of any loans availed in the past.

vii. Security being offered by the borrower in value terms.

The reason behind this is to ensure that loans are given for legal purposes, funds lent are safe and liquid, adequate margins are available, sufficient income or spread is earned, security offered is marketable, and government directives and policies issued from time to time are complied with.

Based on the questionnaire administered to 322 borrowers, responses from these respondents were collected on the most relevant reasons for selecting a bank for availing loan. The first was a rate of interest to be paid (33\%) and then the customer service provided or ease of getting loans $(23 \%)$. These were followed by installments to be paid (11\%), duration of the loan (10\%), and a fee charged $(10 \%)$ in close proximity to each other. The security to be provided $(7 \%)$ and documents to be executed $(6 \%)$ were at the bottom of the list. Thus long-term benefits of the rate of interest and customer service were most relevant in the mind of the borrower while selecting a lender.

Chart 1: Borrowers' reason for selecting lender

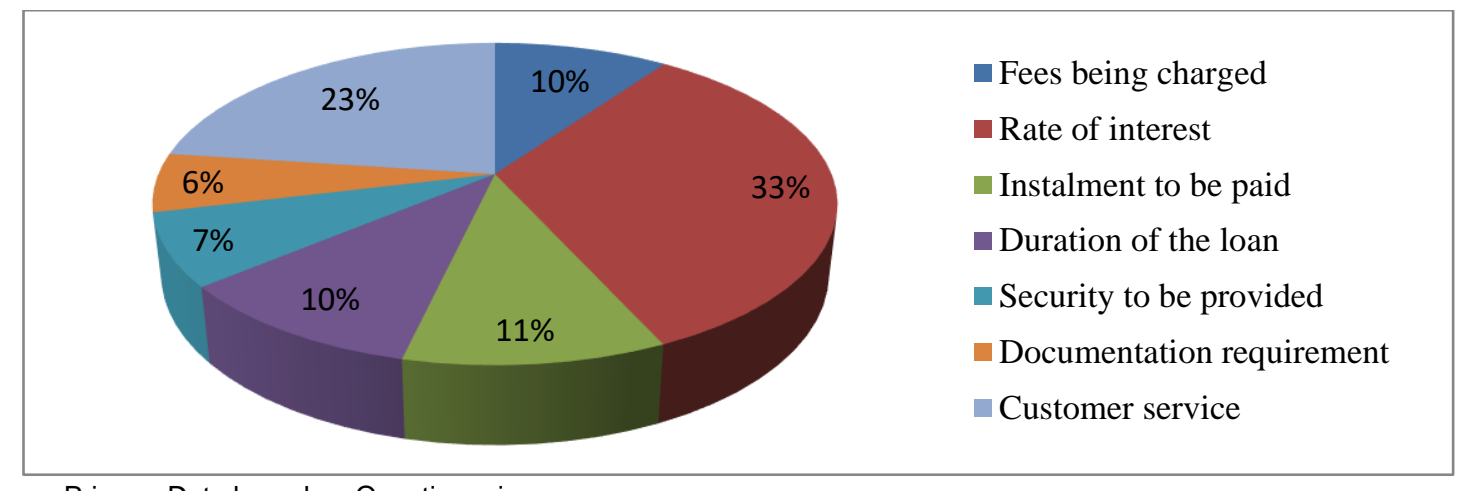

Source: Primary Data based on Questionnaire

Further, the respondents were of the view that bankers mainly look at customers' profiles (24\%), financial performance (24\%), track record of loans availed (18\%), and security is provided (14\%). This was followed by the nature of the industry in which the borrower operates $(8 \%)$, the vintage of business/employment (7\%), and banking habits (5\%). 
Evolving Strategies for the structuring of Working Capital Loans during Covid times: An analysis of select Indian Private Sector Banks

Chart 2: Lenders focus areas

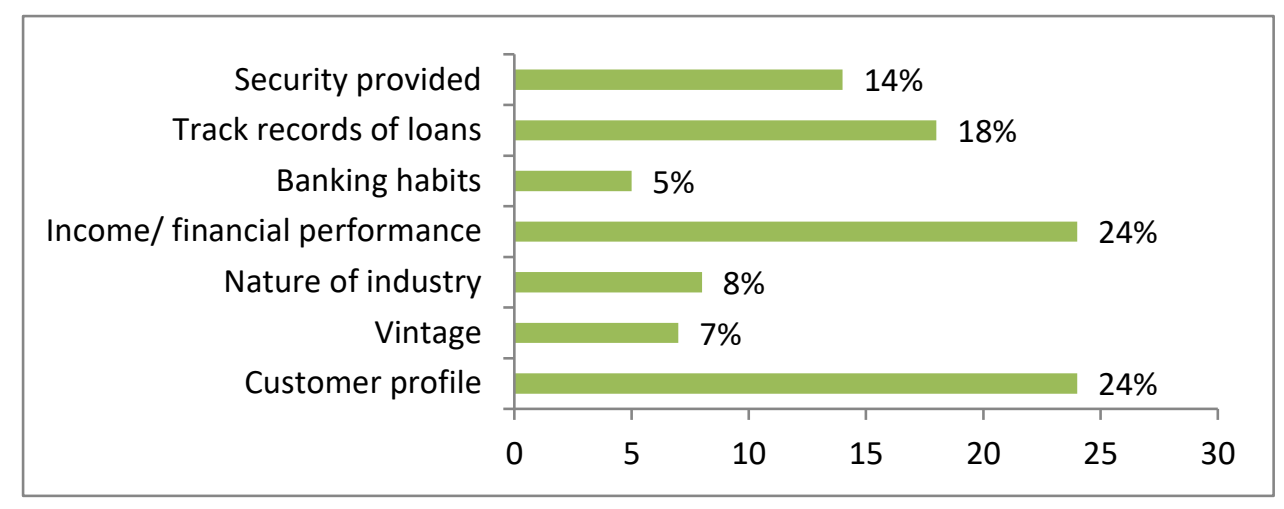

Source: Primary Data based on Questionnaire

During this study, 49 cross-correlations between the seven parameters looked at by borrowers, and seven parameters looked at by bankers while availing, and sanctioning loans were analyzed. These correlations are as below:

Table 2: Correlation between Parameters looked at by borrowers and bankers

\begin{tabular}{|c|c|c|c|c|c|c|c|c|}
\hline & & Fees & $\begin{array}{l}\text { Interest } \\
\text { Rate }\end{array}$ & Installment & Duration & Security & $\begin{array}{c}\text { Documentation } \\
\text { Required }\end{array}$ & $\begin{array}{c}\text { Customer } \\
\text { Service }\end{array}$ \\
\hline \multirow{4}{*}{$\begin{array}{l}\text { Customer } \\
\text { 'Profile }\end{array}$} & Pearson & -.043 & $.211^{* *}$ & .048 & -.104 & .018 & .034 & .044 \\
\hline & Correlation & & & & & & & \\
\hline & Sig. (2-tailed) & .443 & .000 & .394 & .062 & .752 & .545 & .429 \\
\hline & N & 322 & 322 & 322 & 322 & 322 & 322 & 322 \\
\hline \multirow[t]{4}{*}{ Vintage } & Pearson & $.153^{* *}$ & -.011 & $.202 * *$ & $.228 * *$ & $.185^{* *}$ & $.256^{* *}$ & .012 \\
\hline & Correlation & & & & & & & \\
\hline & Sig. (2-tailed) & .006 & .841 & .000 & .000 & .001 & .000 & .828 \\
\hline & $\mathrm{N}$ & 322 & 322 & 322 & 322 & 322 & 322 & 322 \\
\hline \multirow{4}{*}{$\begin{array}{l}\text { Nature of } \\
\text { Industry }\end{array}$} & Pearson & $.155^{* *}$ & -.003 & $.128^{*}$ & $.221 * *$ & $.247^{* *}$ & $.179 * *$ & .043 \\
\hline & Correlation & & & & & & & \\
\hline & Sig. (2-tailed) & .005 & .955 & .021 & .000 & .000 & .001 & .441 \\
\hline & $\mathrm{N}$ & 322 & 322 & 322 & 322 & 322 & 322 & 322 \\
\hline \multirow{4}{*}{$\begin{array}{l}\text { Financial } \\
\text { Performance }\end{array}$} & Pearson & .029 & .059 & $.124^{*}$ & $.173^{* *}$ & $.151^{* *}$ & .024 & .103 \\
\hline & Correlation & & & & & & & \\
\hline & Sig. (2-tailed) & .610 & .294 & .026 & .002 & .007 & .674 & .065 \\
\hline & $N$ & 322 & 322 & 322 & 322 & 322 & 322 & 322 \\
\hline \multirow{4}{*}{$\begin{array}{l}\text { Banking } \\
\text { Habits }\end{array}$} & Pearson & $.147 * *$ & -.060 & $.119 *$ & $.217 * *$ & $.251^{* *}$ & $.267^{* *}$ & $.114^{*}$ \\
\hline & Correlation & & & & & & & \\
\hline & Sig. (2-tailed) & .008 & .280 & .032 & .000 & .000 & .000 & .041 \\
\hline & $\mathrm{N}$ & 322 & 322 & 322 & 322 & 322 & 322 & 322 \\
\hline \multirow{4}{*}{$\begin{array}{l}\text { Repayment } \\
\text { Track Records } \\
\text { (RTR) }\end{array}$} & Pearson & $-.123 *$ & .091 & .067 & $.157 * *$ & $.118^{*}$ & .068 & $.218^{* *}$ \\
\hline & Correlation & & & & & & & \\
\hline & Sig. (2-tailed) & .027 & .103 & .231 & .005 & .034 & .223 & .000 \\
\hline & $\mathrm{N}$ & 322 & 322 & 322 & 322 & 322 & 322 & 322 \\
\hline \multirow[t]{4}{*}{ Security } & Pearson & .039 & -.069 & .031 & $.124^{*}$ & $.161^{* *}$ & $.246 * *$ & $.135 *$ \\
\hline & Correlation & & & & & & & \\
\hline & Sig. (2-tailed) & .485 & .218 & .577 & .026 & .004 & .000 & .015 \\
\hline & $\mathrm{N}$ & 322 & 322 & 322 & 322 & 322 & 322 & 322 \\
\hline
\end{tabular}

**. Correlation is significant at the 0.01 level (2-tailed).

*. Correlation is significant at the 0.05 level (2-tailed).

Source: SPSS output from analysis of primary data based on questionnaire 
It was observed that there was a highly significant relationship between 20 out of 49 parameters (41\%), a significant relationship between 7 out of 49 parameters (14\%), and a negative relationship also between 7 out of 49 parameters (14\%) criteria.

\subsection{Customer Profile}

There is a highly significant correlation between a customer profile and rate of interest (0.211). This implies that while all customers would look for a lower rate of interest, the bank would offer the best rate to the best profile. So better the customer profile, the better the rate the borrower will get, and vice versa.

Similarly, the negative correlation of profile with fees charged (-0.043) and duration of the loan (0.104) shows that lower fees would be charged from high profile customers as they would negotiate for lower or negligible fees. Similarly, shorter duration loans can also be offered to customers with good profiles without fear of default. They would also opt for shorter durations as they would pay lower interest on loans availed by them. On the other hand, higher fees and longer loan duration would be offered to people with poor profiles. Often loans to such profiles can also be rejected by banks.

\subsection{Vintage}

There is a highly significant correlation between the duration for which a borrower has been in a line of business and fees charged to the borrower (0.153). Longer duration shows stability, hence lower risk, therefore lower fees would be charged. On the contrary, a lesser vintage would mean higher risk, which would attract higher fees.

There is also a negative correlation between vintage and rate of interest charged (-0.011). In other words, as vintage increases, the rate of interest can be reduced and vice versa. This also explains the highly significant correlation with installment payable (0.202).

Further, as bankers' comfort increases due to longer vintage or greater work experience, the duration of the loan $(0.228)$ can be modified to suit customers' requirements. This comfort will also have an impact on security (0.185) and documentation (0.256). It will lead to the banks not asking for additional security like a lien on LIC policies, Fixed Deposit receipts, etc. Similarly, the requirement for extra documentation can also be relaxed as employer or business verifications undertaken by the bank would be positive in such cases.

\subsection{Nature of Industry}

There is a highly significant correlation between the nature of industry and fees charged (0.155). The higher the risk attached to the industry, the higher will be the fees charged. So, if the industry from which the borrower belongs is less risky, fees charged will be lower, but if the area of operations of the borrower is in financial problems, to avoid such clients, enhanced fees would be demanded, or loan can also be rejected.

With this in mind, the duration of the loan can also be so altered so as to make the loan unattractive to the client from risky industries. Similarly, an enhanced level of security and greater documentation can be insisted upon by banks such as a registered mortgage rather than an equitable mortgage. All the above validate the highly significant correlation between the nature of industry and duration (0.221), security (0.247), and documentation required (0.179) for granting loans.

This also justifies the negative correlation with the rate of interest $(-0.003)$ as banks do not lend to people associated with those industries which are not economically viable or financially feasible and so could be a source of future NPA.

\subsection{Financial Performance}

There is a highly significant correlation of financial performance with the duration of the loan $(0.173)$ and security required $(0.151)$. This means that borrowers with better financial performance 
have the flexibility to choose the desired loan tenure. Normally, people with higher incomes prefer shorter duration loans with higher loan installments. Banks are also flexible as regards the duration of loans and security to be provided by such high net worth individuals. In fact, they do not insist on a higher level of security as the income of the customers is sufficient to cover the loan installment, and they have a low obligation to income ratio. However, where the financials are weak, the banks can ask for net-worth statements or additional securities to make the case financially more credible.

\subsection{Banking Habits}

There is a highly significant correlation between banking habits with fees charged by banks (0.147), duration of the loan (0.217), security (0.251), and documentation required (0.267) for a loan.

If the bank account shows sufficient balances and credit inflows as well as no penalties, cheque bounce, or minimum balance charges, lower fees can be charged from such borrowers. Similarly, banks can offer loan duration to suit the requirement of the borrowers and can also be lenient towards security and documentation required due to sound banking relationships and healthy banking habits.

The above also justifies the negative correlation with the rate of interest $(-0.060)$ because where banking habits are sound, a lower rate of interest can be offered to the borrower and vice versa. Anyways where banking history is not satisfactory, banks are averse to entertaining such customers.

\subsection{Repayment Track Records (RTRs)}

There is a highly significant correlation between RTRs with the duration of the loan (0.157) and customer service provided (0.218). If the track record of earlier availed loans shows regular repayment, then flexibility in duration can be provided by banks. Similarly, regularity in repayment of earlier loans would result in better customer service.

This leads to the fact that if earlier loan tracks are good, concession in fees to be charged can be given. A bank would not entertain a borrower who has defaulted on any loan, and hence there is a negative correlation of RTRs with fees payable $(-0.123)$ on availing loans.

\subsection{Security}

There is a highly significant correlation between security and documentation required (0.246). Lengthy documentation is required by a bank to ensure that the security taken by them is marketable and legally enforceable. In case of default in a loan, the security taken needs to be liquidated, and this is possible only if the above two criteria are met.

However, there is a negative correlation between security and the rate of interest $(-0.069)$. If the security provided is not up to the mark or the underlying asset is risky, then a risk premium is added, and so the rate of interest increases. Thus risk adjustment in the rate of interest makes it move in the opposite direction to the riskiness of the security.

We can therefore say that the parameters looked at by borrowers and bankers have a definite bearing on each other.

These parameters would, therefore, definitely impact the structure of the loan offered to a client. Considering the dependent variables being the metric credit parameters of fee payable, loan installment and duration of the loan, rate of interest being market-driven, and independent variables being vintage, nature of the industry in which the borrower operates, financial performance, banking habits, and repayment track records (based on the significance of relationship as seen above) banks can make credit models as suggested by multiple regression analysis done hereunder.

They can then arrive at case-specific loan evaluation, adjusting it for the risk perceived by them. 
Table 3: Multiple Regression Analysis for Fee payable by the borrower

\begin{tabular}{|ll|r|r|r|r|r|}
\hline \multicolumn{1}{|c|}{ ANOVA $^{\mathbf{a}}$} \\
Model & \multicolumn{1}{c|}{$\begin{array}{c}\text { Sum of } \\
\text { Squares }\end{array}$} & \multicolumn{1}{c|}{ df } & Mean Square & F & Sig. \\
\hline 1 & Regression & 77.802 & 4 & 19.451 & 5.130 & $.001^{\text {b }}$ \\
& Residual & 1201.903 & 317 & 3.791 & & \\
Total & 1279.705 & 321 & & & \\
\hline
\end{tabular}

Coefficients $^{a}$

\begin{tabular}{|c|c|c|c|c|c|c|}
\hline \multirow{2}{*}{\multicolumn{2}{|c|}{ Model }} & \multicolumn{2}{|c|}{ Unstandardized Coefficients } & \multirow{2}{*}{$\begin{array}{c}\text { Standardized } \\
\text { Coefficients } \\
\text { Beta }\end{array}$} & \multirow[b]{2}{*}{$\mathrm{t}$} & \multirow[b]{2}{*}{ Sig. } \\
\hline & & $\mathrm{B}$ & Std. Error & & & \\
\hline \multirow[t]{5}{*}{1} & (Constant) & 2.358 & .461 & & 5.108 & .000 \\
\hline & Vintage & .104 & .065 & .093 & 1.590 & .113 \\
\hline & Nature of Industry & .110 & .065 & .098 & 1.688 & .092 \\
\hline & Banking Habits & .117 & .055 & .118 & 2.121 & .035 \\
\hline & RTRs & -.131 & .063 & -.115 & -2.096 & .037 \\
\hline
\end{tabular}

a. Dependent Variable: Fees

Source: SPSS output from analysis of primary data based on questionnaire

The ANOVA table under Table 3 shows a significance of 0.001 . Being less than 0.05 at a $5 \%$ significance level, it indicates a relationship that is statistically significant between the dependent variable fee and listed independent variables.

In the coefficient's table, Beta coefficients for banking habits show a slightly higher contribution towards the dependent variable, and its $p$-value $(0.035)$ is less than 0.05 at a $5 \%$ level of significance. Similarly, the p-value of RTR (0.037) is less than 0.05 at a $5 \%$ level of significance though its Beta coefficients are negative.

This indicates that while computing fees, more focus should be laid on these two parameters banking habits and repayment track record of earlier availed loans. As stated earlier, if bank accounts had been showing healthy balances and repayment track records were sound in the past, lower fees could be charged and vice versa.

Table 4: Multiple Regression Analysis for Installment payable by the borrower

\begin{tabular}{|ll|r|r|r|r|c|}
\multicolumn{7}{|c|}{ ANOVA $^{\text {a }}$} \\
Model & & \multicolumn{1}{|c|}{$\begin{array}{c}\text { Sum of } \\
\text { Squares }\end{array}$} & \multicolumn{1}{c|}{ df } & Mean Square & \multicolumn{1}{l|}{ F } & Sig. \\
\hline 1 & Regression & 63.564 & 4 & 15.891 & 5.735 & $.000^{\mathrm{b}}$ \\
& Residual & 878.324 & 317 & 2.771 & & \\
& Total & 941.888 & 321 & & & \\
\hline
\end{tabular}

Coefficients $^{a}$

\begin{tabular}{|c|c|c|c|c|c|c|}
\hline \multirow{2}{*}{\multicolumn{2}{|c|}{ Model }} & \multicolumn{2}{|c|}{ Unstandardized Coefficients } & \multirow{2}{*}{$\begin{array}{c}\begin{array}{c}\text { Standardized } \\
\text { Coefficients }\end{array} \\
\text { Beta } \\
\end{array}$} & \multirow[b]{2}{*}{$\mathrm{t}$} & \multirow[b]{2}{*}{ Sig. } \\
\hline & & B & Std. Error & & & \\
\hline \multirow[t]{5}{*}{1} & (Constant) & 1.910 & .379 & & 5.044 & .000 \\
\hline & Vintage & .168 & .056 & .174 & 2.999 & .003 \\
\hline & Nature of Industry & .042 & .056 & .043 & .746 & .456 \\
\hline & Financial Performance & .138 & .058 & .129 & 2.355 & .019 \\
\hline & Banking Habits & .075 & .047 & .089 & 1.593 & .112 \\
\hline
\end{tabular}

a. Dependent Variable: Installment

Source: SPSS output from analysis of primary data based on questionnaire

ANOVA table under Table 4 shows a significance of 0.000 , which is less than 0.05 at $5 \%$ significance level, indicates a relationship that is statistically significant between the dependent variable installment and listed independent variables. 
In the coefficient's table, Beta coefficients for vintage and financial performance show slightly higher contribution towards dependent variable, and their p-value (0.003) and (0.019) respectively is also less than 0.05 at a $5 \%$ level of significance.

This indicates that while computing installment for loans, more focus should be laid on these two parameters - vintage and financial performance. However, since the financial positions of businesses have been adversely impacted by lockdowns, this historical data should be used as an indicator rather than a benchmark, and vintage or stability should be relied upon to a greater extent while ascertaining repayability of installments.

Table 5: Multiple Regression Analysis for the duration of loan availed by the borrower

\begin{tabular}{|ll|r|r|r|r|r|}
\hline \multicolumn{1}{|c|}{ ANOVA $^{\text {a }}$} \\
\hline Model & & \multicolumn{1}{c|}{$\begin{array}{c}\text { Sum of } \\
\text { Squares }\end{array}$} & \multicolumn{1}{c|}{ df } & Mean Square & \multicolumn{1}{c|}{$\mathrm{F}$} & Sig. \\
\hline 1 & Regression & 161.727 & 5 & 32.345 & 11.533 & $.000^{\mathrm{b}}$ \\
& Residual & 886.261 & 316 & 2.805 & & \\
& Total & 1047.988 & 321 & & & \\
\hline
\end{tabular}

Coefficients $^{a}$

\begin{tabular}{|c|c|c|c|c|c|c|}
\hline \multirow{2}{*}{\multicolumn{2}{|c|}{ Model }} & \multicolumn{2}{|c|}{ Unstandardized Coefficients } & \multirow{2}{*}{$\begin{array}{c}\text { Standardized } \\
\text { Coefficients } \\
\text { Beta } \\
\end{array}$} & \multirow[b]{2}{*}{$\mathrm{t}$} & \multirow[b]{2}{*}{ Sig. } \\
\hline & & $\mathrm{B}$ & Std. Error & & & \\
\hline \multirow[t]{6}{*}{1} & (Constant) & 1.053 & .418 & & 2.520 & .012 \\
\hline & Vintage & .165 & .056 & .163 & 2.932 & .004 \\
\hline & Nature of Industry & .137 & .056 & .135 & 2.431 & .016 \\
\hline & Financial Performance & .172 & .059 & .153 & 2.899 & .004 \\
\hline & Banking Habits & .153 & .047 & .171 & 3.229 & .001 \\
\hline & RTRs & .156 & .054 & .150 & 2.863 & .004 \\
\hline
\end{tabular}

a. Dependent Variable: Duration

Source: SPSS output from analysis of primary data based on questionnaire

The ANOVA table under Table 5 shows the significance of 0.000 and is less than 0.05 at a $5 \%$ significance level. It indicates a relationship that is statistically significant between the dependent variable loan duration and listed independent variables.

In the coefficient's table, Beta coefficients for all the parameters show similar contributions towards the dependent variable, and similarly, their $p$ values are also less than 0.05 at a $5 \%$ level of significance. Still, the focus should be laid in the order of banking habits, vintage, financial performance, RTRs, and finally, nature of industry before deciding the duration of the loan to be given. Again, as banking, financials, and track records may be skewed currently, vintage and industry to which a borrower belongs, both of which show past and future stability, would be more reliable parameters.

Once the installment payable and duration of loan have been worked out by using an appropriate model comprising of the above parameters, rate of interest being predetermined, the loan amount can be triangulated upon by the bank. This would be case-specific and derived after a thorough analysis of each case by credit officials. Therefore this risk-adjusted loan structuring would reduce the incidence of default and improve the quality of the asset portfolio held by the bank.

\section{Conclusions \& Suggestions}

Based on this study, we can conclude that the null hypothesis of there being no significant relationship between credit parameters looked at by bankers and borrowers can be rejected as there was a highly significant relationship between $41 \%$, a significant relationship between $14 \%$, and negative relationship between $14 \%$ criteria, i.e., almost $69 \%$ of the correlations were significant in nature. 
Further, for borrowers, the selection of lenders is rate-sensitive. While the rate of interest is a macroeconomic factor beyond the control of individual banks, the benefit, as and when available, should definitely be passed on to the borrowers so as to retain them.

Similarly, the highest level of service should be provided to all customers to retain them. Though the level of customer service provided till now depended on the performance of earlier loans availed, customer-centric service can definitely be a game-changer, particularly post the merger of public sectors banks. This would increase the competition for private sector banks, and they would need to be on their toes even more.

Banks, on the other hand, look at the profile of customers to assess the current standing and status in his business circle. They also check the financial soundness to ensure the long-term survival, sustainability, and solvency of the business so that the money advanced is recovered with ease. Linked to this is the repayment track record of earlier loans availed by the client. Timely payment gives an indication of repay-ability of the current facility being sought and hence works in favor of the customer.

However, in the current scenario, neither looking at financials that have been hit adversely by the pandemic nor looking at repayment track records for which RBI gave a moratorium of two quarters would help banks take credit decisions.

We, therefore, suggest a case-to-case evaluation, adjusted as per risk perceived by banks.

i. The fee to be charged should be based on banking habits, including track records of earlier loans availed by the customer, as this shows financial discipline.

ii. The duration of the loan should be based on the length for which the customer has been in business and the nature of the industry in which he operates. These parameters depict the financial control and steadiness of the business. Also, as stated earlier, banking habits, financial performance or profitability of the business, and repayment track records of earlier availed loans would no longer be viable in the covid scenario.

iii. While computing loan installment focus should be on vintage or the duration for which customer has been in business as longer vintage shows greater stability and experience, thereby making money lent safer and less risky.

iv. Security to be given by a customer should be linked to the duration for which a person has been in business or service and the industry in which he operates. Banking habits, including the performance of earlier loans taken by a customer, can only point not predict serviceability of loan now being availed. In case of weakness in any of the above parameters or doubt, additional security should be asked for.

Based on the above and regression analysis undertaken, risk-adjusted dynamic scorecards should be devised by banks for giving working capital loans to SMEs, including agri-based units.

Thus, looking at the relationship between credit parameters, banks should be able to provide customer-specific, risk-adjusted, scorecard-based loans rather than template-driven ones (Patnaik, Satpathy, and Samal, 2017). Since the thorough analysis of each case would be undertaken, the incidence of default and occurrence of non-performing assets would be minimized, resulting in improved asset portfolio quality of banks.

\section{References}

1. Ahmad, Z.; Jegadeeshwaran, M. (2013). "Comparative Study on NPA Management of Nationalized Banks", Retrieved from International Journal of Marketing, Financial Services and Management Research, 2(8)

2. Banerjee, R.; Verma, D.; Jaiswal, B. (2018). "Non-performing assets: a comparative study of the Indian commercial banks", International Journal of Social Relevance and Concern, 6(2), pp. 5-21.

3. Catherine, N. (2020). "Credit Risk Management and Financial Performance: A Case of Bank of Africa (U) Limited", Open Journal of Business and Management, 8, pp. 30-38. 
4. Chaitra, K.S.; Vasu, V. (2018). "Comparative Study on Non-Performing Assets of Selected Private and Public Sector Banks", International Research Journal of Management Sociology \& Humanity, 9(3), pp. 128-144.

5. Chaudhary, K.; Sharma, M. (2011). "Performance of Indian Public Sector Banks and Private Sector Banks: A Comparative Study", International Journal of Innovation, Management and Technology, 2(3)

6. Dhanya, P.; Vanaja K. (2018). "A Study on Credit Appraisal System in India with Special Reference to South Indian Banks", International Journal of Trend in Scientific Research and Development, 3(1), pp.126-130

7. Gupta, B. (2012). "A Comparative Study of Non-Performing Assets of SBI \& Associates and Other Public Sector Banks", SIT Journal of Management, 2(3), pp. 175-189

8. Sharma, A.K. \& Kumar, S. (2011). "Effect of Working Capital Management on Firm Profitability: Empirical Evidence from India", Global Business Review, 12(1), pp. 159 - 173.

9. Kumar, R. B.; Subbarao, B.; Kusuma, G. (2018). Genesis for increase of NPAs in Indian banks - an empirical analysis. Journal of Banking and Finance Management, 1 (1), 1-8.

10.Mishra, M.K.; Pawaskar, J.R. (2017). "A study of non-performing assets and its impact on banking sector", Journal for Research, 3(1), pp. 1-5.

11.Mittal, R.K.; Suneja, D. (2017). "The problem of rising non-performing assets in banking sector in India: comparative analysis of public and private sector banks", International Journal of Management, IT and Engineering, 7(7), pp. 384-398.

12.Palli, N. (2019). "Non-Performing Assets in India: An analysis over the years", Asian Banking and Finance. https://members.irglobal.com/file/af717d5cfb718626815afd3945918598.pdf

13.Patnaik, B. C. M.; Satpathy, I.; Samal N.R., (2017), "Retail Banking Challenges and Latest Trends in India", International Journal of Economic Research, 14(12), pp. 1-11.

14.Sahni, D.; Seth, D.C. (2017). "Non-performing assets (NPAs) in Indian commercial banks", International Journal of Engineering Science and Computing, 7(4), pp. 6243-6247.

15.Saptarshi Ray. (2020). "A Study of Non-performing Asset Management as a Strategic Approach to Ensure Sustainability among the Public Sector Banks in India", IIMS Journal of Management Science, Indian Journals.com, 11(1), pp. 16-34.

16.Sengupta, R.; Vardhan, H. (2017). "Non-performing assets in Indian banks: this time it is different", Indira Gandhi Institute of Development and Research Economic and Political Weekly, 52(12), pp. 85-95.

17.Shah, V.; Sharma S. (2016). "A Comparative Study of NPA In ICICI Bank and HDFC Bank", Abhinav National Monthly Refereed Journal of Research in Commerce \& Management, 5(2), pp. 15-23.

18.Singh, J. (2013). "Recovery of NPAs in Indian commercial banks", International Journal of Transformation in Business, 2(3).

19.Singh, V.R. (2016). "A Study of Non-Performing Assets of Commercial Banks and it's recovery in India", Annual Research Journal of SCMS, Pune, 4, pp. 110-125.

20.https://www.dnb.co.in/learning-and-economic-solutions/publications/indias-top-banks-2017

21.https://www.rbi.org.in/

22.https://www.axisbank.com

23.https://www.hdfcbank.com

24.https://www.icicibank.com

25.https://www.kotak.com

26.https://www.yesbank.in 